\title{
Comparative evaluation of Irvingia gabonensis seed fat extract and other bases in promethazine hydrochloride suppository formulations
}

\author{
Olusola AREMU $1,3 *$ (D), Yetunde ISIMI ${ }^{1}$ (D), Kokonne EKERE ${ }^{1}$ (D), Olawale AGBAJE ${ }^{1}$ (D), \\ Olubunmi OLAYEMI ${ }^{1}$ (D), Musiliu ADEDOKUN ${ }^{1,4}$ (D), Martins EMEJE ${ }^{2}$ \\ 1 Department of Pharmaceutical Technology and Raw Materials Development, National Institute for Pharmaceutical \\ Research and Development, Abuja, Nigeria. \\ 2 Centre for Nanomedicine and Biophysical Drug Delivery, National Institute for Pharmaceutical Research and \\ Development, Abuja, Nigeria. \\ 3 Department of Pharmaceutics and Industrial Pharmacy, Faculty of Pharmaceutical Sciences, University of Ilorin, \\ Ilorin, Nigeria. \\ 4 Department of Pharmaceutics and Pharmaceutical Technology, Faculty of Pharmacy, University of Uyo, Uyo, \\ Nigeria. \\ * Corresponding Author. E-mail: solabank@yahoo.com (O.A.); Tel. +23-480-3325 9890.
}

Received: 01 February 2019 / Revised: 22 April 2019 / Accepted: 23 May 2019

\begin{abstract}
A study has been made on the formulation and evaluation of promethazine hydrochloride suppositories using dika fat (DF) from Irvingia gabonensis seeds as a base comparatively with both water and fatty soluble bases. Rectal suppositories containing promethazine hydrochloride $(25 \mathrm{mg})$ in pre-calibrated mould were prepared by fusion method using DF, macrogol (MG), cocoa butter (CB) and cocoa butter $+10 \% \mathrm{w} / \mathrm{w}$ (weight by weight) beeswax (CBW) as bases. Thereafter the suppositories were characterized using parameters such as appearance, crushing strength, weight variation, melting point, $\mathrm{pH}$, liquefaction time, content uniformity, and in vitro release in accordance with standard procedures. Results obtained indicated that the bases used generally could be ranked in the order of DF $>$ CB $>\mathrm{MG}>\mathrm{CBW}$ in terms of favourable physicochemical properties investigated. The foregoing indicates that DF has promising potential and could be a substitute suppository base in the formulation of promethazine hydrochloride suppositories
\end{abstract}

KEYWORDS: Formulation; suppositories; promethazine hydrochloride; Dika fat.

\section{INTRODUCTION}

Wild mango (Irvingia gabonensis, Aubry Lecomte ex O'Rork-Baill, family: Simarubaceae) grows naturally in parts of Africa extending from Senegal to the Sudan and to the South of Angola. The fruit, which is not related botanically to the well-known, cultivated mango Mangifera indica L. It is available between July and October. It grows about $40 \mathrm{~m}$ in height with a straight bole of up to $100 \mathrm{~cm}$ in diameter. It can be found in tropics, where it is highly-valued for multiple uses, one of which is the edible seeds used in soups and as a food flavor [1]. Due to the pleasant roasty-nutty aroma generated upon thermal processing, the roasted seeds are commonly used in Africa as a flavoring in traditional dishes. Numerous data are reported in the literature on nutritional and dietary aspects of the seeds [2-9].

Irvingia gabonensis fruits are edible, and their use in traditional medicine has been documented for the treatment of gastrointestinal or hepatic disorders, diarrhea, infections, and as a purgative. Recently, the seeds have become available on the U.S. market as a dietary supplement and have shown high in vitro antioxidant capacity, significant effects in body weight loss, blood lipid decreases, and a lowering of plasma glucose in

How to cite this article: Aremu O, Isimi Y, Ekere K, Agbaje O, Olayemi O, Adedokun M, Emeje M. Comparative evaluation of Irvingia gabonensis seed fat extract and other bases in promethazine hydrochloride suppository formulations. J Res Pharm. 2020; 24(2): 240-250. 
experimental animal or human subject studies [5, 10-13]. For several reasons, there is growing interest in the pharma industry to make use of natural products in research and development; for example, dika fat, a vegetable lipid obtained from the seeds has been reported in several studies [14-18]. The fat is solid at ambient tropical weather and can only be isolated from its plant source by means of expression or solvent extraction. It is soluble in several organic solvents such as n-hexane, cyclohexane, petroleum ether, diethylether, chloroform, toluene, acetone and ethanol. The fat is amber in colour and has a faint odour. Several physicochemical properties of dika fat such as iodine value, saponification number, free fatty acid and differential scanning calorimetry have been determined [19].

Several investigators have reported different functional properties of the mucilage from the seeds; for example, Odeku \& Patani [16] reported the binding property in tablet formulation and concluded that, incorporation of dika nut mucilage increased disintegration and dissolution times and as such could be used to modify drug release while Isimi et al [14] investigated the emulsifying and suspending properties with a conclusion that, the mucilage produced more stable emulsions and suspensions at the concentrations evaluated than when acacia or tragacanth was used. In a similar but different study, Onyechi \& Udeala [17] studied the lubricant effect of dika fat in tableting and concluded that dika fat did not confer negative effects on hardness, disintegration and dissolution of the formulated tablets. In more advanced studies reported by Ofoefule et al [20] and Okore [21], dika fat was employed as an effective career in sustained release tablet preparations and as a promising film coating agent in microencapsulation

Suppository is a solid delivery system designed for insertion into rectum where they melt, dissolve or disperse and exert a local, or a systemic effect. Suppositories can be prepared by using lipophilic hydrophilic bases. They are a dosage form being developed as an alternative to existing ones in order to overcome certain challenges often encountered in their administration [22]. Promethazine is a phenothiazine derivative with antihistaminic, sedative and antiemetic properties. It selectively blocks peripheral $\mathrm{H}_{1}$ receptors thereby diminishing the effects of histamine on effector cells as an antihistamine. Its anti-emetic effect is through the blockage of action of acetylcholine and this explains the benefit in reducing nausea and vomiting [23]. The challenges associated with usage of oral or parenteral drugs in critically ill patients suffering from nausea and vomiting necessitated consideration of rectal route as a remedy. The choice of dika fat from plant source is to explore possible solution commonly associated with usage of cocoa butter with different polymorphs and softening temperatures in the tropical regions.

The present study involves evaluation of dika fat as a suppository base comparatively with three other bases namely cocoa butter, cocoa butter $+10 \%$ beeswax (Fatty bases) and macrogol (water soluble bases) using an antiemetic agent, promethazine hydrochloride as the model drug.

\section{RESULTS}

Dika seeds gave a percentage yield of $51.3 \% \mathrm{w} / \mathrm{w}$ of the fat. The fat obtained was a light yellow coloured solid with characteristic odour. Table 1 shows the different suppository formulations and their composition. Figure 1 shows the FTIR spectroscopy results obtained for the different suppository formulations with or without their respective bases. The results of the characterization of promethazine hydrochloride suppositories including control formulations are all presented in Table 2. Drug content after formulation and production must exhibit uniformity from dose to dose in compliance with standard specifications. The percentage content of the drug in all the formulations is graphically presented in Figure 2. Medicaments must be available for therapeutic activity from dosage forms at the site of action. For rectal administration, the drug is expected to either diffuse or partition out of the bases after melting, dispersed or dissolved in body fluids. This is to be followed by local effect or absorption if meant for systemic effect. The release rates of the various formulations in this study is presented in Figure 3 while the release kinetics of the different formulations is shown in Table 3. 
A

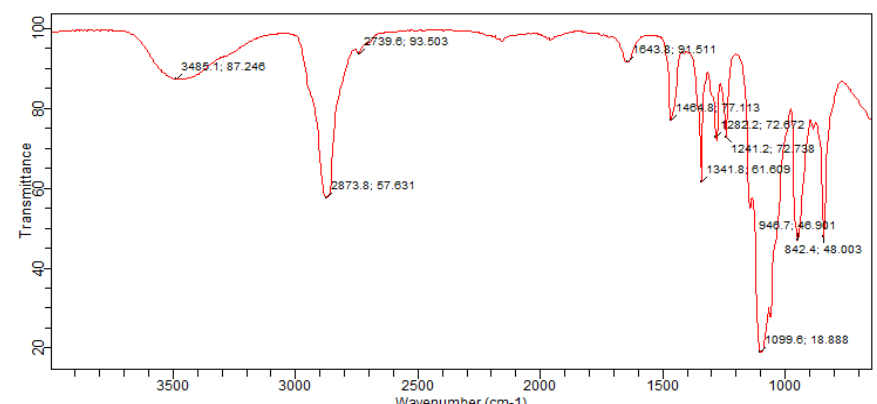

B

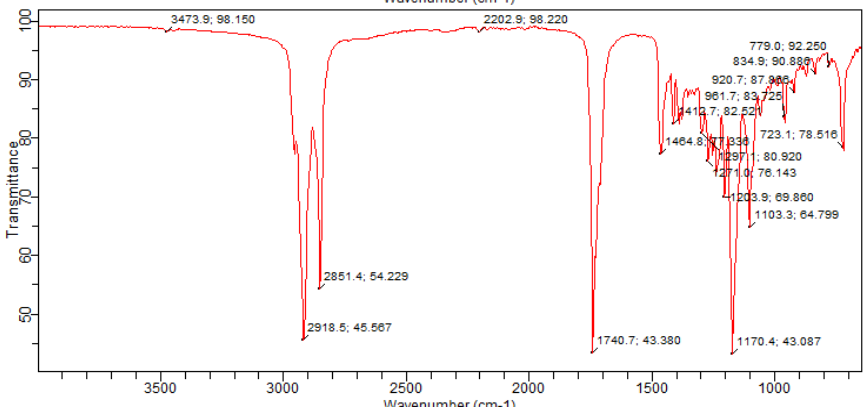

C

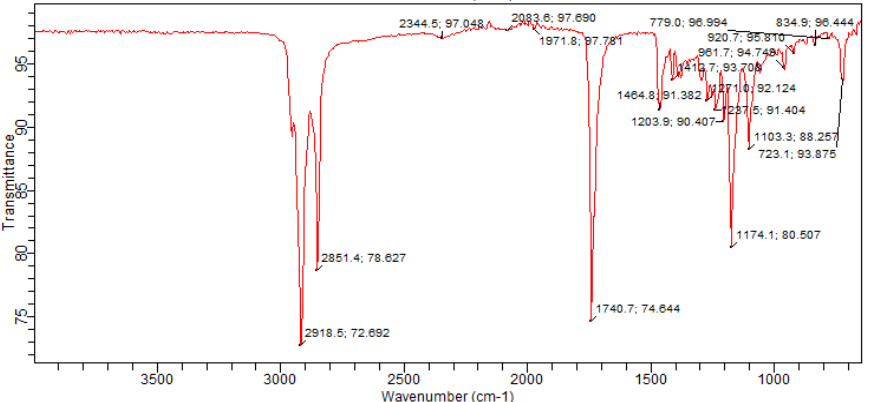

D

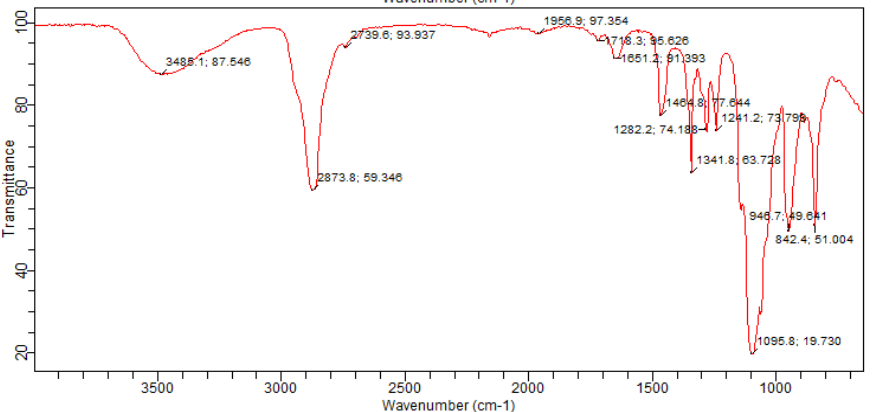

E

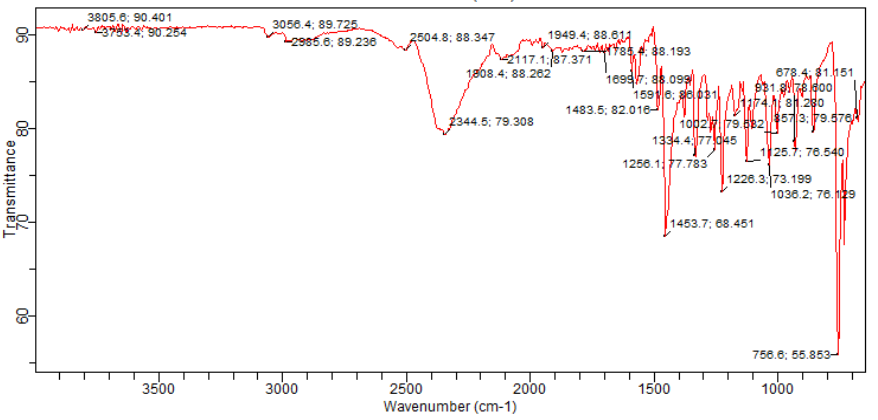

Figure 1. FTIR spectrum of Macrogol (A), Dika fat (B), Promethazine HCl+Dika fat (C), Promethazine $\mathrm{HCl}+\mathrm{Macrogol}(\mathrm{D})$, Promethazine $\mathrm{HCl}(\mathrm{E})$. 
Table 1. Different suppository formulations and their composition.

\begin{tabular}{lcccc}
\hline Ingredients & PDF & PMG & PCB & PCBW \\
\hline Promethazine Hydrochloride & $1 \mathrm{~g}$ & $1 \mathrm{~g}$ & $1 \mathrm{~g}$ & $1 \mathrm{~g}$ \\
Dika fat to & $80.0 \mathrm{~g}$ & - & - & - \\
Cocoa butter to & - & - & $63.7 \mathrm{~g}$ & - \\
Cocoa butter + $\mathbf{1 0} \%$ w/w Beeswax to & - & - & - & $75.5 \mathrm{~g}$ \\
PEG $\mathbf{1 0 0 0}(\mathbf{8 0} \% \mathbf{w} / \mathbf{w})+$ PEG 4000 $(\mathbf{2 0} \% \mathbf{w} / \mathbf{w})$ to & - & $98.3 \mathrm{~g}$ & - & - \\
\hline
\end{tabular}

$\mathrm{PDF}=$ PromethazineHCl+Dikafat,PMG=PromethazineHCl+Macrogol base, $\mathrm{PCB}=$ Promethazine $\mathrm{HCl}+$ cocoa butter, $\mathrm{PCBW}=$ Promethazine $\mathrm{HCl}+$ cocoa butter $+10 \% \mathrm{w} / \mathrm{w}$ beeswax .

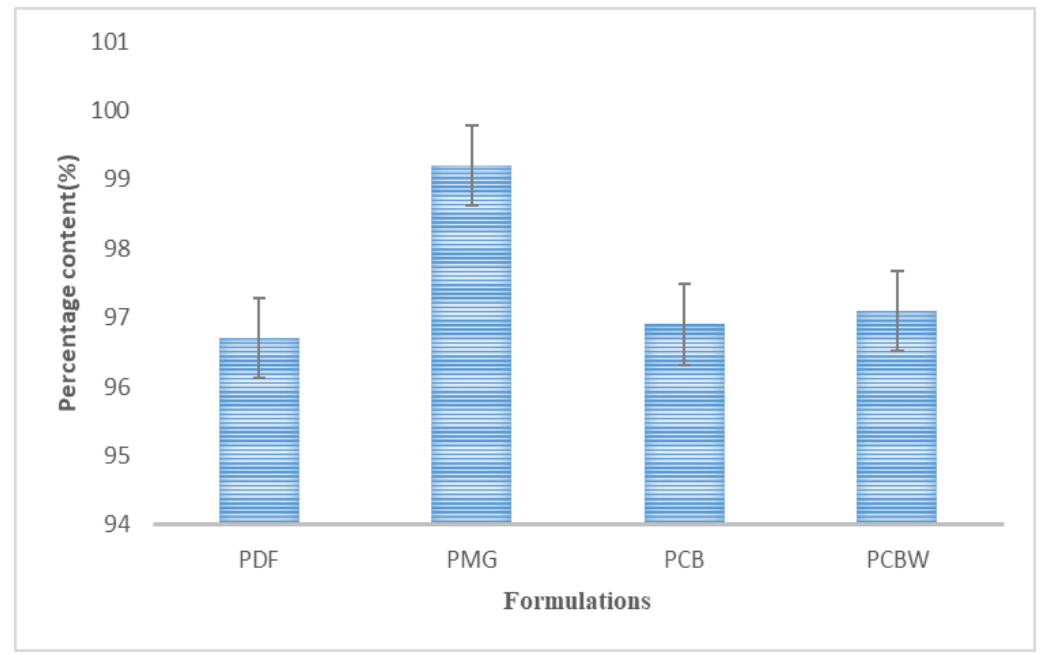

Figure 2. Percentage content of Promethazine Hydrochloride suppositories.

$\mathrm{PDF}=$ Promethazine $\mathrm{HCl}+$ Dika fat, $\mathrm{PMG}=$ Promethazine $\mathrm{HCl}+\mathrm{Macrogol}$ base, $\mathrm{PCB}=$ Promethazine $\mathrm{HCl}+$ cocoa butter, $\mathrm{PCBW}=$ Promethazine $\mathrm{HCl}+$ cocoa butter $+10 \% \mathrm{w} / \mathrm{w}$ beeswax.

Table 2. Physicochemical and release parameters of the suppositories.

\begin{tabular}{|c|c|c|c|c|c|c|c|c|}
\hline $\begin{array}{l}\text { Physical and } \\
\text { release parameters }\end{array}$ & PDF & DF & PMG & MG & РCB & CB & PCBW & CBW \\
\hline Shape & Torpedo & Torpedo & Torpedo & Torpedo & Torpedo & Torpedo & Torpedo & Torpedo \\
\hline Colour & $\begin{array}{l}\text { Light } \\
\text { yellowish }\end{array}$ & $\begin{array}{l}\text { Light } \\
\text { yellowish }\end{array}$ & $\begin{array}{l}\text { Off - } \\
\text { white }\end{array}$ & $\begin{array}{l}\text { Off - } \\
\text { white }\end{array}$ & $\begin{array}{l}\text { Light } \\
\text { yellowish }\end{array}$ & $\begin{array}{l}\text { Light } \\
\text { yellowish }\end{array}$ & $\begin{array}{l}\text { Light } \\
\text { yellowish }\end{array}$ & $\begin{array}{c}\text { Light } \\
\text { yellowish }\end{array}$ \\
\hline Mean weight(g) & $\begin{array}{c}1.95 \\
\pm 0.01\end{array}$ & - & $\begin{array}{c}2.43 \\
\pm 0.03\end{array}$ & - & $\begin{array}{c}2.01 \\
\pm 0.01\end{array}$ & - & $\begin{array}{c}1.94 \\
\pm 0.01\end{array}$ & - \\
\hline $\begin{array}{l}\text { Hardness/crushing } \\
\text { strength(N) }\end{array}$ & $\begin{array}{l}19.02 \\
\pm 1.11\end{array}$ & $\begin{array}{l}18.80 \\
\pm 1.10\end{array}$ & $\begin{array}{l}11.16 \\
\pm 1.77\end{array}$ & $\begin{array}{l}11.12 \\
\pm 1.56\end{array}$ & $\begin{array}{l}17.64 \\
\pm 1.53\end{array}$ & $\begin{array}{l}17.42 \\
\pm 1.61\end{array}$ & $\begin{array}{l}19.42 \\
\pm 1.27\end{array}$ & $\begin{array}{l}18.90 \\
\pm 1.30\end{array}$ \\
\hline Melting point $\left({ }^{\circ} \mathrm{C}\right)$ & $\begin{array}{l}38.10 \\
\pm 0.68\end{array}$ & $\begin{array}{l}37.60 \\
\pm 0.55\end{array}$ & $\begin{array}{l}37.44 \\
\pm 0.61\end{array}$ & $\begin{array}{l}36.40 \\
\pm 0.62\end{array}$ & $\begin{array}{l}33.02 \\
\pm 0.55\end{array}$ & $\begin{array}{l}32.10 \\
\pm 0.66\end{array}$ & $\begin{array}{l}36.74 \\
\pm 0.98\end{array}$ & $\begin{array}{l}36.70 \\
\pm 0.83\end{array}$ \\
\hline $\begin{array}{l}\text { Liquefaction } \\
\text { time(min) }\end{array}$ & $\begin{array}{l}32.00 \\
\pm 2.12\end{array}$ & $\begin{array}{l}29.00 \\
\pm 2.01\end{array}$ & $\begin{array}{l}33.00 \\
\pm 0.72\end{array}$ & $\begin{array}{l}32.10 \\
\pm 2.16\end{array}$ & $\begin{array}{l}12.80 \\
\pm 0.84\end{array}$ & $\begin{array}{l}13.20 \\
\pm 0.63\end{array}$ & $\begin{array}{l}17.20 \\
\pm 1.64\end{array}$ & $\begin{array}{l}18.90 \\
\pm 1.53\end{array}$ \\
\hline $\mathrm{pH}$ & $\begin{array}{c}5.52 \\
\pm 0.02\end{array}$ & $\begin{array}{r}6.23 \\
\pm 0.01\end{array}$ & $\begin{array}{c}4.41 \\
\pm 0.02\end{array}$ & $\begin{array}{c}5.21 \\
\pm 0.03\end{array}$ & $\begin{array}{c}4.81 \\
\pm 0.01\end{array}$ & $\begin{array}{c}5.72 \\
\pm 0.03\end{array}$ & $\begin{array}{c}4.44 \\
\pm 0.02\end{array}$ & $\begin{array}{c}5.23 \\
\pm 0.01\end{array}$ \\
\hline $\begin{array}{l}\text { Displacement } \\
\text { value }\end{array}$ & 0.31 & - & 0.52 & - & 2.87 & - & 1.07 & - \\
\hline
\end{tabular}

OPDF=Promethazin e $\mathrm{HCl}+$ Dika fat, $\mathrm{PMG}=$ Promethazine $\mathrm{HCl}+$ Macrogol base, $\mathrm{PCB}=$ Promethazine $\mathrm{HCl}+$ cocoa butter, PCBW=Promethazine $\mathrm{HCl}+$ cocoa butter $+10 \% \mathrm{w} / \mathrm{w}$ beeswax. 


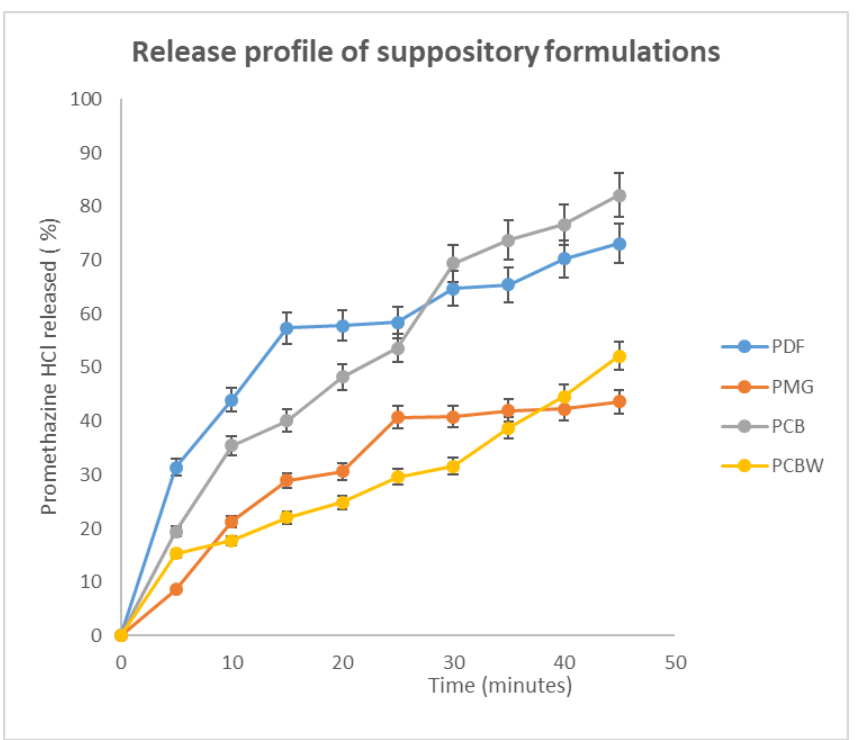

Figure 3. Release profile of Promethazine hydrochloride suppositories.

$\mathrm{PDF}=$ Promethazine $\mathrm{HCl}+$ Dika fat, $\mathrm{PMG}=$ Promethazine $\mathrm{HCl}+$ Macrogol base, $\mathrm{PCB}=$ Promethazine $\mathrm{HCl}+\mathrm{cocoa}$ butter, PCBW=Promethazine $\mathrm{HCl}+$ cocoa butter $+10 \% \mathrm{w} / \mathrm{w}$ beeswax.

Table 3. Release rate constant and model fitting parameters for release kinetics of different Promethazine hydrochloride suppository formulations.

\begin{tabular}{lllccc}
\hline $\begin{array}{l}\text { Release } \\
\text { kinetic model }\end{array}$ & $\begin{array}{l}\text { Selection } \\
\text { parameter }\end{array}$ & PDF & PMG & PCB & PCBW \\
\hline Zero-order & $\mathrm{K}_{0}(\mathrm{~min})$ & 0.895 & 0.797 & 1.542 & 0.895 \\
& $\mathrm{R}^{2}$ & 0.870 & 0.827 & 0.970 & 0.971 \\
First-order & $\mathrm{K}_{1}(\mathrm{mg} / \mathrm{min})$ & 0.007 & 0.013 & 0.014 & 0.015 \\
& $\mathrm{R}^{2}$ & 0.788 & 0.684 & 0.888 & 0.995 \\
Higuchi & $\mathrm{K}_{\mathrm{H}}\left(\mathrm{mg} / \mathrm{min}^{1 / 2}\right)$ & 8.434 & 7.663 & 14.180 & 7.923 \\
& $\mathrm{R}^{2}$ & 0.934 & 0.914 & 0.981 & 0.913 \\
Korsmeyer- & $\mathrm{K}_{\mathrm{KP}}\left(\mathrm{mg} / \mathrm{min}^{\mathrm{n}}\right)$ & 0.359 & 0.699 & 0.645 & 0.552 \\
Peppas & $\mathrm{R}^{2}$ & 0.950 & 0.908 & 0.984 & 0.924 \\
\hline
\end{tabular}

$\mathrm{PDF}=$ Promethazine $\mathrm{HCl}+$ Dika fat, $\mathrm{PMG}=$ Promethazine $\mathrm{HCl}+$ Macrogol base, $\mathrm{PCB}=$ Promethazine $\mathrm{HCl}+\mathrm{cocoa}$ butter, $\mathrm{PCBW}=$ Promethazine $\mathrm{HCl}+$ cocoa butter $+10 \% \mathrm{w} / \mathrm{w}$ beeswax

\section{DISCUSSION}

Dika fat yields $51.3 \% \mathrm{w} / \mathrm{w}$. The fat obtained was a light yellow coloured solid with its own characteristic odour. The yield can sustain commercial production because of the availability of the seeds all year round. It grows naturally in parts of Africa including Nigeria, although the perennial tree generally produces fruits between July and October, it is found all year round because it is highly-valued for multiple uses including as edible seeds in soups and as a food [1].

FTIR spectroscopic studies were conducted to study any interaction between the drug and the suppositories bases used in the formulation of promethazine suppositories. The FTIR spectra of PMZ, dika fat, Macrogol as well as suppositories containing PMZ with dika fat and PMZ with Macrogol are represented in Figure 1(A-E). The PMZ spectrum showed principal peaks at 2200-2480 $\mathrm{cm}^{-1}$ for NH+ stretching, at 1453 $\mathrm{cm}^{-1}$ for $\mathrm{CH}_{3}$ and $\mathrm{CH}_{2}$ bending and $756 \mathrm{~cm}-1$ for out of plane $\mathrm{CH}$ bending of disubstituted aromatic respectively. The prominent bands displayed by PMZ spectrum are also present in the suppository containing dika fat at $2344 \mathrm{~cm}^{-1}$ and $723 \mathrm{~cm}^{-1}$ (Figure 1C) respectively. The presence of these same absorption bands as the pure drug demonstrates the absence of interaction between drug and suppository base (dika fat) used. 
However, there was complete deletion of the disubstituted aromatic band and a considerable shrinkage of the absorption bands representing $\mathrm{NH}^{+}$stretching for $\mathrm{CH}_{3}$ and $\mathrm{CH}_{2}$ bending in the suppository containing Macrogol (Figure 1C), implying some level of interactions between the drug and suppository base (Macrogol) used. The FTIR spectra of unloaded suppositories (Figures 1A and B) were also taken to note any changes that occur during preparation. All the unloaded suppositories exhibited the spectra characteristic of dika fat and Macrogol, whereas it could be concluded that, the FTIR spectra of loaded suppositories show dominant peaks of drug molecule, but intensity weakens due to physical interaction between suppositories base (especially Macrogol) and drug molecule; this interaction may actually be due to weak ionic interaction between them.

The dissected suppositories were found to be uniform in appearance and contained no air bubbles. There were equally no holes or brittle, thus, the suppositories were not fragile and could withstand transportation and other mechanical exposures [24].

All the suppositories prepared with four different bases satisfied the BP requirement for weight uniformity as can be seen in Table 2. Not more than two individual suppositories deviated from the average weight by more than $5 \%$ and no suppository differed from the average weight by more than $10 \%$ [25]. The relative standard deviations (RSD) of the mean weight of the suppositories were less than $3.5 \%$.

The suppositories were evaluated for hardness or crushing strength as a measure of their mechanical strength to withstand handling and transportation. The results of the crushing strength of different bases without medicament showed significant $(\mathrm{p}<0.05)$ differences. The order of the strengths are CBW $(20.2 \mathrm{~N})>\mathrm{DF}$ $(18.8 \mathrm{~N})>\mathrm{CB}(17.42)>\mathrm{MG}(11.12 \mathrm{~N})$ while that of those containing medicaments had similar strengths with the blank bases. They are of the order; PCBW $(19.42 \mathrm{~N})>$ PDF $(19.02 \mathrm{~N})>$ PCB $(17.64)>$ PMG $(11.16 \mathrm{~N})$. These values except that of PMG fall within the range reported by Azhgikhin [26] as acceptable forces (17.7-19.6N). The inclusion of promethazine hydrochloride (PHCL) did not have appreciable effect on the crushing strengths of the suppositories, probably because of its low concentration in the bases.

The $\mathrm{pH}$ of the formulations ought to be compatible with the body $\mathrm{pH}$, as any adverse $\mathrm{pH}$ may result in adverse reactions. The mean $\mathrm{pH}$ of all the formulations including the placebos are presented in Table 2. It was found that the $\mathrm{pH}$ of drug-loaded suppositories were lower than those of their corresponding unloaded suppositories (placebos). The $\mathrm{pH}$ of promethazine hydrochloride is acidic, this must have contributed to the lowering of the $\mathrm{pH}$ of the formulations. The $\mathrm{pH}$ of PDF $(5.52 \pm 0.02)$ was the only one near the $\mathrm{pH}$ of rectum (6-8). The remaining formulations tend towards acidic region. The implication of this is that, patients may experience irritation at the site of action during usage. Hence there is need for $\mathrm{pH}$ balance in the rectum. Modifications can be made to the $\mathrm{pH}$ of the formulations in order to obtain an ideal $\mathrm{pH}$ value which poses little or no risk to the body cavity.

The melting point of cocoa butter with and without the drug was $32.1^{\circ} \mathrm{C}$ as can be seen in Table 2 . This is quite low for storage in the tropics. This necessitated the inclusion of $10 \% \mathrm{w} / \mathrm{w}$ beeswax that meet ideal suppository base. The melting points of PDF, PMG, PCBW are $38.1^{\circ} \mathrm{C}, 37.8^{\circ} \mathrm{C}$ and $36.7^{\circ} \mathrm{C}$ respectively. These were found to fall within the acceptable range for suppository formulations [27]. However, the melting points of PDF and PMG were found to be higher than their respective placebo bases which are $37.6^{\circ} \mathrm{C}$ and $36.4^{\circ} \mathrm{C}$ respectively. This increase which is probably as a result of inclusion of the medicament may impact on the release of the drug as this may prolong liquefaction time [28]. Liquefaction testing provides information on the behavior of a suppository when subjected to a maximum temperature of $37^{\circ} \mathrm{C}$ [29]. The liquefaction times for all the suppositories showed significant $(\mathrm{p}<0.05)$ difference. They are of the order PMG $(33.0 \pm 2.121)>\mathrm{PDF}$ $(32.0 \pm 2.121)>$ PCBW $(17.2 \pm 1.643)>$ PCB $(12.8 \pm 1.643)$. These values fall closely to within acceptable limits. Liquefaction should not take longer than 30 minutes [30]. A suppository that does not liquefy easily may exert irritant action on the rectal mucosa and release of the drug from the base may take longer time. The liquefaction times of PMG and PDF in this study appear ideal, the gradual dissolution or melting of this suppositories may enhance steady release of the drug from the bases. There is also possibility of reliable, higher rectum retention time as opposed to those of PCB and PCBW which may melt faster than necessary due to their low liquefaction times and could even wash away from the rectum without releasing the active ingredient. 
The mean drug content for the suppositories met the USP requirement for the content uniformity. The mean drug content of the four batches fell within 96.7- 99.2\% as can be seen in Figure 1. Variation of active ingredient content in suppositories is usually due to the inappropriate mixing of the molten bases or due to sedimentation by gravity [31]. The conformity of the mean drug content implies that fusion method is appropriate for the preparation of promethazine hydrochloride suppositories and proper mixing of the bases and promethazine hydrochloride powder was achieved by the use of glass bead and magnetic stirrer.

Drug release is an important property of a therapeutic system, constituting a prerequisite to absorption of the therapeutic agent and one that contributes to the rate and extent of active availability to the body when intended for systemic action or easy availability when it is for local action. The in vitro dissolution studies revealed that release rate was higher in oil soluble bases compared to the water soluble base. Suppositories produced with macrogol exhibited poor release characteristics with $43.6 \%$ of drug released in 45 minutes as can be seen in Figure 2. Promethazine hydrochloride is a water soluble drug, the affinity of macrogol for water soluble drugs may promote the entrapment of the drug and hinder the drug release as observed in this study. Similar report in the study by Hosny [32] shows increased rate of diazepam release from PEG suppositories due to low affinity between the drug and the base. Another report by Realdon et al [33] also documented that drugs with low aqueous solubility are more easily released from PEG suppositories while the release rate from those that are more aqueous soluble is less.

This result also corroborates our FTIR result which revealed some level of chemical interaction between macrogol and promethazine hydrochloride as explained earlier. Worthy of note too, is the post production color change just 5 days after storage from light yellow to pinkish colouration, a further confirmation of interaction. Promethazine hydrochloride has less affinity for lipophilic bases, hence there is higher tendency to diffuse to the surrounding aqueous medium, thus water-soluble drugs are preferred in fatty base suppositories. Cocoa butter suppositories have the highest percentage of drug released as can be seen in Figure 2 after 45 minutes and this might be due to lower melting point, softening point and liquefaction time of the base than other bases.

Studies on drug release kinetics provide important information into the behavior of the vehicles and the drug in a system. In this study, the results of the release studies were analyzed using Zero-order, Firstorder and Higuchi release models. Adjusted Coefficient of Determination (R adjusted) was used in selecting the best-fit release method. Based on the selection criteria, PCBW fitted well into first order $\left(R^{2}=0.995\right)$, while PDF $\left(R^{2}=0.934\right), \operatorname{PMG}\left(R^{2}=0.914\right)$ and PCB $\left(R^{2}=0.98\right)$ may fit into Higuchi square root model.

The release mechanism of promethazine hydrochloride from the suppositories was analyzed with Korsmeyer-peppas model. The release exponents, $\mathrm{n}$, for all the formulations range from 0.36 to 0.69 . The value of ' $n$ ' for PDF is 0.36, indicating Fickian diffusion mechanism, diffusion that is controlled by the concentration gradient of the drug in the base. The values of ' $n$ ' for PMG, PCB and PCBW were greater than 0.5 suggesting non-Fickian diffusion mechanisms of drug release from the suppositories. Here the release of drug from the bases involves melting of the base, partitioning and diffusion of the drug through the molten base into the dissolution medium rather than one type of release phenomenon postulated by Higuchi model [34] NonFickian diffusion mechanism is able to ensure better release of the medicament, faster absorption and timely onset of action.

\section{CONCLUSION}

The promethazine hydrochloride suppositories using dika fat and three other bases were successfully formulated and evaluated. This study shows that, of the four suppository bases interrogated viz; Dika Fat, macrogol, cocoa butter and blend of cocoa butter and beeswax, Dika fat which is obtained from an abundant plant source in the tropics may be a very good substitute to the more expensive bases. The in vivo performance of the optimized formulations is ongoing in our laboratory and will form a separate report. 


\section{MATERIALS AND METHODS}

\subsection{Extraction process}

The plant material, Irvingia gabonensis seeds were purchased from Karmo market, Abuja, Nigeria. The material was identified and authenticated at the herbarium section of National Institute for Pharmaceutical Research and Development (NIPRD), Abuja where a voucher specimen (NIPRD/H/6983) was deposited. The seeds were milled into powder form, $380 \mathrm{~g}$ of the pulverized seed was weighed out using the analytical balance (Mettler Toledo, Switzerland) and then macerated with n-hexane at a ratio of 1:10. The mixture was left to stand for 72 hours after which the supernatant was decanted and heated in water bath at about $100^{\circ} \mathrm{C}$ for n-hexane to evaporate. The dika fat was collected, weighed and stored at room temperature.

Materials used include promethazine hydrochloride powder (Sigma Aldrich), n-hexane (Lobachemie, India), Aluminum foil (Novena foil, China), Liquid paraffin, Beeswax, Cocoa butter, Polyethylene glycol 1000 and 4000 (EmproveExp Merck, Germany), Sodium dihydrogen orthophosphate, Sodium hydroxide (Analar, Merck, Germany), distilled water (NIPRD Laboratory, Nigeria).

\subsection{Preparation of promethazine hydrochloride suppositories using different bases}

Pour moulding method was used for the production of the suppositories in pre-calibrated mould with different bases. Calculated displacement values were used in determining the various final quantities of the bases used. The suppository mould was properly cleaned and lubricated with liquid paraffin. Appropriate quantities of bases were weighed differently into a beaker and placed in a water bath at about $60^{\circ} \mathrm{C}$ to melt. A quantity of promethazine hydrochloride ( $25 \mathrm{mg}$ per suppository) was weighed and vigorously stirred together with melted bases at about $50^{\circ} \mathrm{C}$ using a magnetic stirrer to allow for homogenous mixture. This procedure was repeated for production of placebo suppositories as control formulations. The mixture was poured into the mould until it overflowed, the top was filled as the solidifying mixture was shrinking. The mould content was allowed to solidify. The mould was then unscrewed, suppositories were removed and wrapped in aluminum foil until further experiments were carried out.

\subsection{Evaluation of suppositories}

\subsubsection{Appearance}

Six suppositories were randomly selected from each batch including placebo batches and they were observed as an intact unit and also after splitting them longitudinally. Colour, odour, shape, the presence or absence of fissuring, pitting, exudation, sedimentation, and the migration of the active ingredients were also assessed.

\subsubsection{Weight uniformity}

The weight uniformity test was carried out as described in the British Pharmacopoeia [25]. Twenty suppositories were randomly selected from each batch of the formulations, weighed individually using an analytical balance (Mettler Toledo, Switzerland), the mean weights and standard deviations were calculated.

\subsubsection{Determination of $p H$}

The $\mathrm{pH}$ of each melted suppository was determined using a $\mathrm{pH}$ meter (Jenway, UK). All measurements were an average of three determinations and expressed as mean \pm S.D.

\subsubsection{Hardness/ Crushing strength}

The crushing strength, a measure of mechanical strength or hardness of the suppository was determined using the hardness tester (Erweka GmbH Germany). Six suppositories randomly selected from each batch were used for the determination. The weight under which each suppository collapsed was recorded in Kilogram force and converted to Newton. 


\subsubsection{Liquefaction time}

Six suppositories were randomly selected from each batch, $60 \mathrm{~mL}$ of phosphate buffer with a $\mathrm{pH}$ of 7.4 was heated up to $37^{\circ} \mathrm{C} \pm 1^{\circ} \mathrm{C}$ and maintained, the suppository was dropped inside the buffer and the time taken for the suppository to completely dissolve or melt was noted as the liquefaction time.

\subsubsection{Melting point determination}

The melting point of promethazine hydrochloride suppositories were determined according to the method reported by Adebayo \& Akala [35]. A suppository, randomly selected from each batch was placed in a beaker with a thermometer inserted. The beaker was immersed in a water bath at about $6 \mathrm{~cm}$ depth regulated to a gradual temperature increase of $1^{\circ} \mathrm{C} / 2 \mathrm{~min}$. The temperatures at which the suppository sample began to melt was taken as melting point. The results obtained were average of five determinations. The melting point of bland suppository bases was also similarly determined.

\subsubsection{Content uniformity}

Six suppositories were randomly selected from each batch and assayed individually for drug content. A suppository was weighed and placed in a beaker containing $60 \mathrm{ml}$ of phosphate buffer solution (pH 7.4) that was pre-heated to $37^{\circ} \mathrm{C}$. The temperature of the phosphate buffer was maintained at $37 \pm 1^{\circ} \mathrm{C}$. When the suppository had been completely melted and dispersed, the mixture was made up to $100 \mathrm{ml}$ with the phosphate buffer. The mixture was stirred at $100 \mathrm{rpm}$ for 5 minutes using magnetic stirrer and thereafter filtered through a cotton plug. The absorbance of $5 \mathrm{ml}$ of filtered portions was measured in UV-Vis spectrophotometer (Jenway 6505, UK) at $250 \mathrm{~nm}$. The concentration of the promethazine hydrochloride in the solution was calculated from a standard Beer- Lambert curve.

\subsubsection{Release studies}

The magnetic stirrer and beaker assembly was adopted [36]. The medium consisted of freshly prepared $100 \mathrm{ml}$ of sodium phosphate buffer solution of $\mathrm{pH} 7.4$ and was maintained at temperature of $37 \pm 1^{\circ} \mathrm{C}$. In each case, one suppository from each batch was placed in the phosphate buffer and the magnetic stirrer was set at $50 \mathrm{rpm}$. At 5 minutes interval and over a period of 45 minutes, $10 \mathrm{ml}$ portion of the release medium were withdrawn with syringe and was filtered through a cotton plug. The volume of the release medium was kept constant by replacing the withdrawn with phosphate butter at each interval. Absorbance of $5 \mathrm{ml}$ of filtered portions was determined using UV-Vis spectrophotometer (Jenway 6505, UK) at $250 \mathrm{~nm}$. The various absorbance values were thereafter converted to the concentrations with reference to Beer- Lambert plot.

\subsubsection{Fourier transform infrared spectroscopy (FT-IR)}

The IR spectra of the suppositories with and without their respective bases were run as $\mathrm{KBr}$ pellets on impact 410 Nicolet FTIR spectrometer in the frequency range $4000-500 \mathrm{~cm}^{-1}$.

Acknowledgements: The authors are grateful to the technical staff of the Department of Pharmaceutical Technology and Raw Materials Development, National Institute for Pharmaceutical Research and Development (NIPRD) for their assistance during the period this study was conducted and also Mallam Muazam of the Department of Medicinal Plant Research and Traditional Medicine for his help in the identification of the plant material.

Author contributions: Concept - O.A; Design - O.A., Y.I. ; Supervision - O.A., Y.I., K.E; Resource- O.A., O.O; Materials - M.A; Data Collection and/or Processing - O.O., K.E., M.A., O.A.; Analysis and/or Interpretation - O.A., O.O., K.E., M.A., M.E.; Literature Search - O.A; Writing - M.E., O.A.; Critical Reviews - O.A., Y.I., K.E., O.A., O.O., M.A., M.E.

Conflict of interest statement: The authors declare no conflict of interest. 


\section{REFERENCES}

[1] Ogunsina BS, Koya OA, Adeosun OO. Deformation and fracture of dika nut (Irvingia gabonensis) under uni-axial compressive loading. Int. Agrophys. 2008; 22(3): 249-253.

[2\} Ayivor JE, Debrah SK, Nuviadenu C, Forson A. Evaluation of elemental contents of Wild Mango (Irvingia gabonensis) fruit in Ghana. Adv J Food Sci Tech. 2011; 3(5): 381-384.

[3] Ekpe OO, Umoh IB, Eka OU. Effect of a typical rural processing method on the proximate composition and amino acid profile of bush mango seeds (Irvingia gabonensis). Afr J Food Agr Nutr Dev. 2007; 7(1): 1-12.

[4] Ndamitso MM, Mathew JT, Shaba EY, Salihu AB, Ogunmiloro OJ. Comparative nutritional compositions of Irvingia gabonensis (Wild bush mango) seeds and Abelmoschus esculaentus (Okra) pods. Nig J Chem Res. 2012; 17: 50-58.

[5] Ngondi JL, Oben JE, Minka SR. The effect of Irvingia gabonensis seeds on body weight and blood lipids of obese subjects in Cameroon. Lipids Health Dis. 2005; 4: 12. [CrossRef]

[6] Njoku OU, Ugwuanyi JO. Nutritional and toxicology ical properties of Dika fat (Irvingia gabonensis). J Herbs Spices Med Plt. 1997; 4(4): 53-58. [CrossRef]

[7] Onimawo IA, Oteno F, Orokpo G, Akubor PI. Physicochemical and nutrient evaluation of African bush mango (Irvingia gabonensis) seeds and pulp. Plt foods Hum Nutr. 2003; 58: 1-6. [CrossRef]

[8] Onojah PK, Musa F, Ugwuowo EN. Comparative studies on the proximate composition and anti-nutrient content of the cotyledons of two species of Irvingia (Ogbono) sold in Anyigba main market, Kogi State, Nigeria. J Chem Soc. 2018; 43(2): 98-107.

[9] Sahoré AD, Koffi LB, Kouamé, AM. Technical sheet of Irvingia gabonensis seeds preparation in Ivory Coast. Am J Food Sci Tech. 2013; 1(3): 42-44.

[10] Adamson I, Okafor C, Abu-Bakare A. Erythrocyte membrane ATPases in diabetes: Effect of Dikanut (Irvingia gabonensis). Enzyme. 1986; 36: 212-215. [CrossRef]

[11] Adamson I, Okafor C, Abu-Bakare A. A supplement of Dikanut (Irvingia gabonensis) improves treatment of type II diabetics. West Afric J Med. 1990; 9: 108-115.

[12] Kuyooro SE, Abam EO, Agbede, EB. Hypolipidemic effects of Irvingia gabonensis- supplemented diets in male albino rats. Biochem Anal Biochem. 2017; 6(2): 1-5. [CrossRef]

[13] Ngondi JL, Djiotsa EJ, Fossouo Z, Oben J. Hypoglycaemic effect of the methanol extract of Irvingia gabonensis seeds on streptozotocin diabetic rats. Afr J Trad Cam. 2006; 3(4): 74-77.

[14] Isimi CY, Kunle O, Bangudu AB. Some emulsifying and suspending properties of the mucilage extracted from kernels of Irvingia gabonensis. Boll Chim Farm. 2000; 139: 199-204.

[15] Ndjouenkeu R, Akingbala J, Oguntimein G. Emulsifying properties of three African food hydrocolloids: okra (Hibiscus esculentus), dika nut (Irvingia gabonensis) and khan (Belschmiedia sp.). Plant Food Hum Nutr (Formerly Qualitas Plantarum). 1997; 51: 245-255. [CrossRef\}

[16] Odeku OA, Patani B. Evaluation of dika nut mucilage (Irvingia gabonensis) as a binding agent in metronidazole tablet formulation. Pharm Dev Technol. 2005; 10: 439-446. [CrossRef]

[17] Onyechi JO, Udeala OK. The tableting properties of dika fat lubricant. Drug Dev Ind Pharm. 1990; 16: 1203-1216. [CrossRef]

[18] Udeala OK, Onyechi JO, Agu SI. Preliminary evaluation of dika fat, a new tablet lubricant. J Pharma Pharmacol. 1980; 32: 6-9. [CrossRef]

[19] Onyechi JO. Preformulation compatibility screening of dika fat-drug mixtures using differential scanning calorimetry. Bioresearch. 2009; 7(1): 465-469. [CrossRef] 
[20] Ofoefule SI, Chukwu A, Okore VC, Ugwah MO. Use of dika fat in the formulation of sustained release frusemide encapsulated granules. Boll Chim Farm. 1997; 136: 646.

[21] Okore VC. Effect of dika fat content of a barrier film coating on the kinetics of drug release from swelling polymeric systems. Boll Chim Farm. 2000; 139: 21-25.

[22] Boylan CJ, Swarbrick J. Ency Pharm Tech. 2002; 1(2): 932-955.

[23] Cantisani C, Ricci S, Grieco T, Paolino G, Faina V, Silvestri E, Calvieri S. Topical promethazine side effects: our experience and review of the literature. Biomed Res Int. 2013; 151509. [CrossRef]

[24] Ofoefule SI, Chukwu A, Nwankwo C, Orisakwe, OE. In-Vitro Properties of Ciprofloxacin Suppositories Formulated with Glycerogelatin and Theobroma Oil Bases. Boll Chim Farmaceutico. 1998; 137(9): 341-344.

[25] British Pharmacopoeia. British Pharmacopoeia Office: MHRA, 151 Buckingham Palace road, London SW1W9SZ 2013.

[26] Azhgikhin IS. Determination of the hardness of suppository bases using Kaminskii's device. Aptechn Delo. 1965; 14: 14-19.

[27] Lund W. The Pharmaceutical codex, Principles and practice of Pharmaceutics. The Pharmaceutical Press, London, 1994, pp. 170-176.

[28] Taylor O, Igwilo C I, Adeoye DI, Awosika OO. In vitro release of paracetamol from various suppository formulations of purified shea butter. J Pharm Sci Pharm Prac. 1993; 2: 93-99.

[29] Kaewnopparat S, Kaewnopparat N. Formulation and Evaluation of Vaginal Suppositories Containing Lactobacillus. WASET. 2009; 55: 640-643.

[30] Sahoo CK, Sudhakar M, Ramana DV, Satyanarayana K. A Discussion on quality control of suppositories. MJPMS. 2017; 6(3): 16-18.

[31] Carter SJ. Dispensing for Pharmaceutical students. CBS Pub., Delhi, 1987, pp. 231-252.

[32] Hosny E. Formulation, in-vitro release and ex-vivo spasmolytic effects of mebeverine hydrochloride suppositories containing polycarbophil or polysorbate 80. Int J Pharm. 1996; 142(2): 163-168. [CrossRef]

[33] Realdon N, Ragazzi E, Ragazzi E. Effect of drug solubility on in vitro availability rate from suppositories with polyethylene glycol excipients. Pharmazie. 2001; 56: 163-167.

[34] Okubanjo OO, Odeku OA. Effect of interacting variables on the mechanical and release properties of chloroquine phosphate suppositories. Acta Pharm Sci. 2009; 51(3): 281-288.

[36] Adebayo AS, Akala EO. Kinetics model for the in vitro release of an hydrophilic drug (Amodiaquine) from fat-based Suppositories. Int J Arts Technol. 2005; 2: 1-11.

[36] Attama AA, Ezeabasili SI, Adikwu MU. In vitro release of salicylic acid from suppositories formulated with blends of goat fat and palm kernel oil. J Pharm Res Dev. 2000; 5: 17-22.

This is an open access article which is publicly available on our journal's website under Institutional Repository at http://dspace.marmara.edu.tr. 